ORP-56504

Revision 1

\title{
Halide, Chromate, and Phosphate Impacts on LAW Glass for Dynamic Flowsheet. 24590-WTP-MCR-PET-09-0037, Rev. 1
}

Prepared for the U.S. Department of Energy

Assistant Secretary for Environmental Management

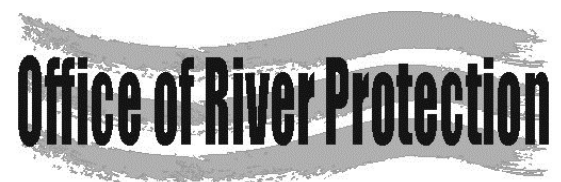

P.O. Box 450

Richland, Washington 99352 
ORP-56504

Revision 1

\section{Halide, Chromate, and Phosphate Impacts on LAW Glass for Dynamic Flowsheet. 24590-WTP-MCR-PET-09-0037, Rev. 1}

R. Gimpel

Bechtel National, Inc.

\section{Date Published}

June 2010

Prepared for the U.S. Department of Energy

Assistant Secretary for Environmental Management

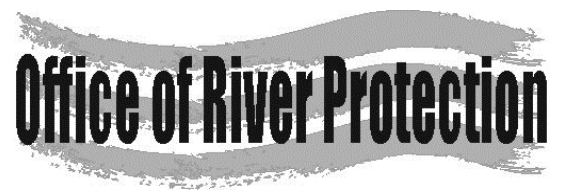

P.O. Box 450

Richland, Washington 99352

\section{APPROVED}

By Julia Raymer at 10:43 am, Dec 16, 2013 
ORP-56504

Revision 1

TRADEMARK DISCLAIMER

Reference herein to any specific commercial product, process, or service by tradename, trademark, manufacturer, or otherwise, does not necessarily constitute or imply its endorsement, recommendation, or favoring by the United States Government or any agency thereof or its contractors or subcontractors.

This report has been reproduced from the best available copy.

Printed in the United States of America 
24590-WTP-MCR-PET-09-0037, Rev 1

Model Change Request (MCR)

Page 1 of 1

PART 1: REQUEST INITIATION (to be completed by Requester)

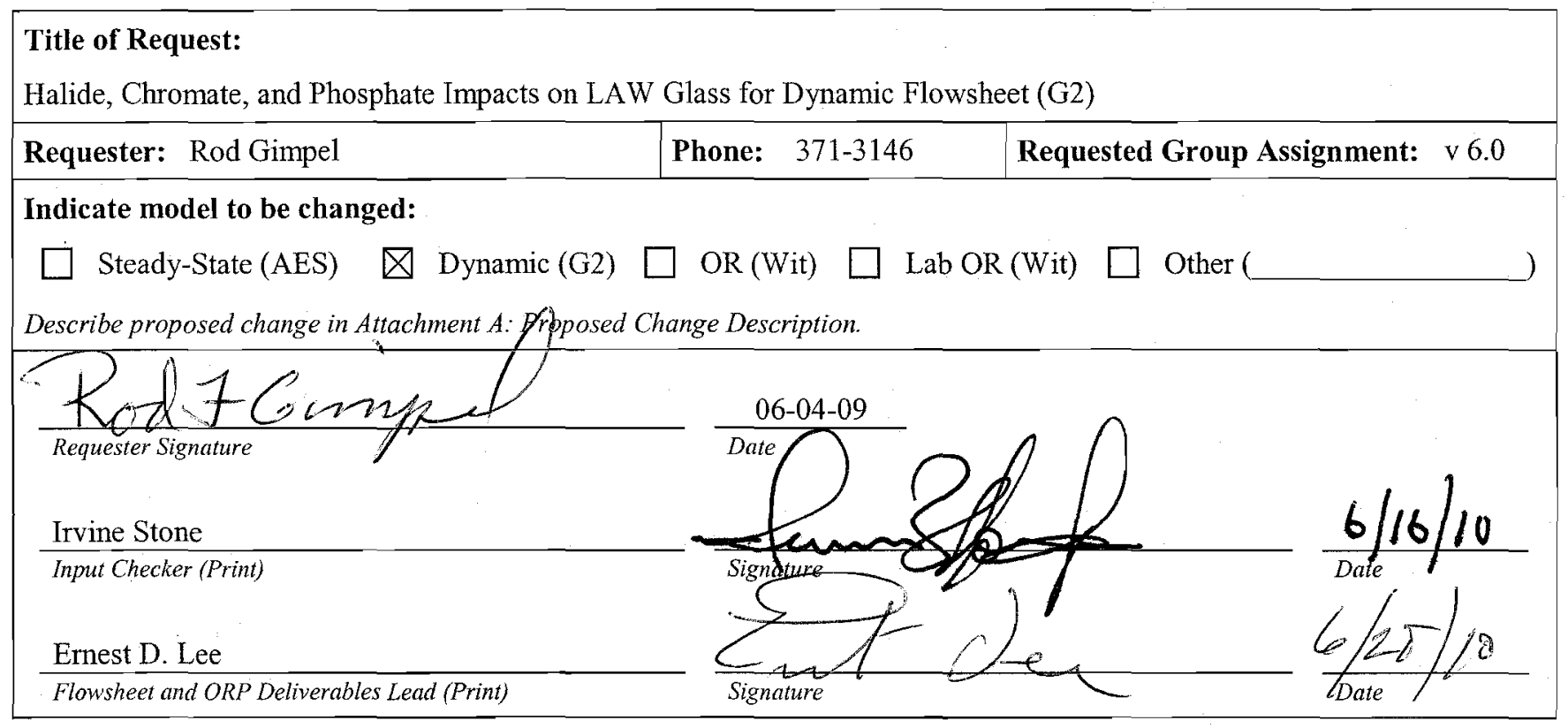

PART 2: REQUEST TRACKING (to be completed by Configuration Management Designed)

\begin{tabular}{|l|l|}
\hline Date Submitted to CM: $6-\sqrt{5}-10$ & Actual Model Group Assignment: $\sqrt{6.0}$ \\
\hline Date Scoping Completed: $N A$ & Date V\&V Completed: NA \\
\hline
\end{tabular}

PART 3: REQUEST SCOPING (to be completed by Modeler)

\begin{tabular}{|llllll}
\hline Estimated Time to Complete Change Request: & Total: & 20 Implementation: 4 & Run: $/ 6$ \\
\hline
\end{tabular}

PART 4: REQUEST CLOSURE (to be completed by Configuration Management Designed)

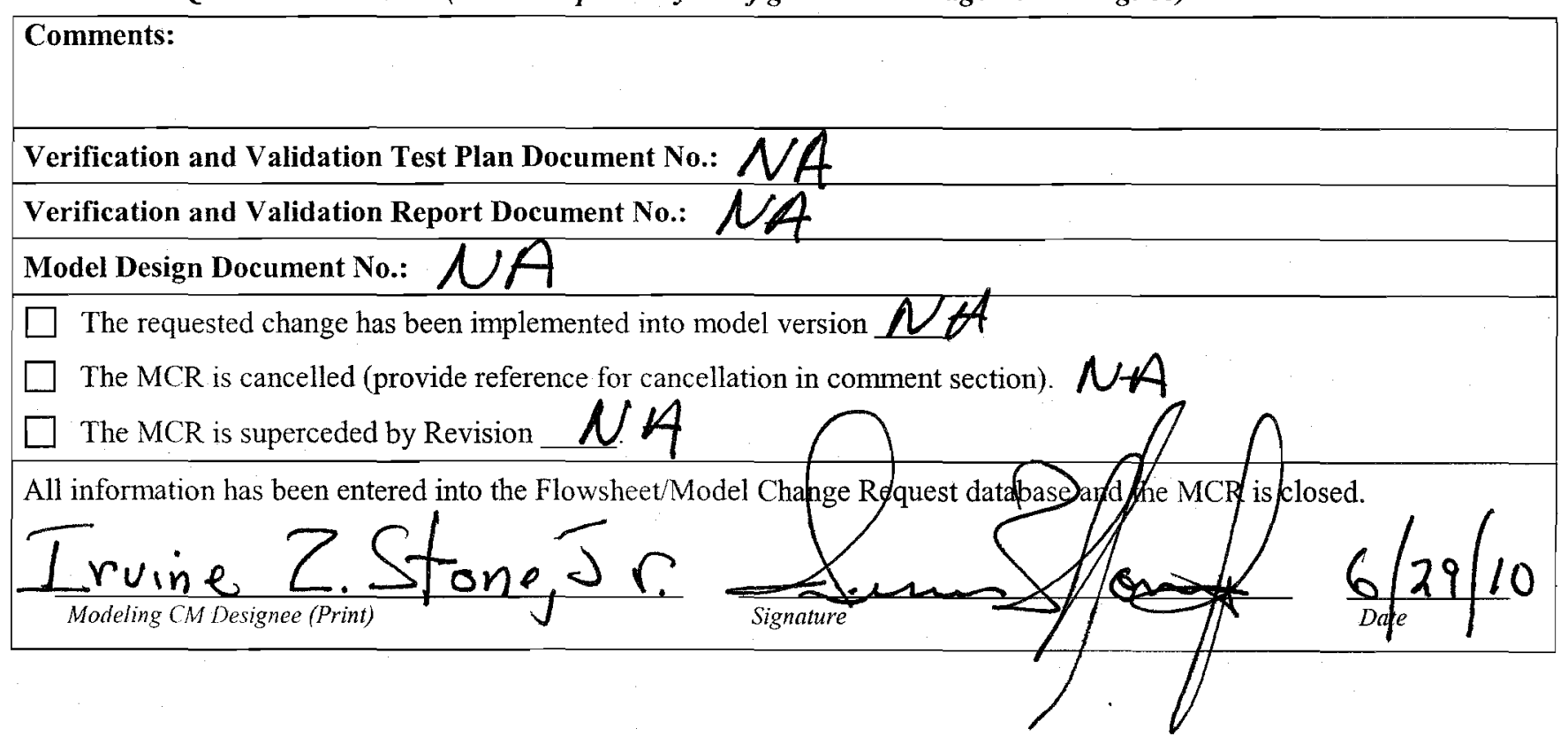

24590-PT-F00002 Rev 6 (7/1/2008)

1

Ref: 24590-WTP-GPP-PT-015 
Total No. Pages: $\mathcal{S}^{2}$

\section{Model Change Request (MCR)}

\section{Attachment A: Proposed Change Description}

Additional pages may be added to the Proposed Change Description, as necessary. All pages must have the MCR number and be numbered sequentially as Page A-X. Enter N/A in any sections that are not applicable.

Facility (indicate all facilities impacted by proposed change):

Pretreatment $\quad$ LAW Vitrification $\quad \square$ HLW Vitrification $\quad \square$ Balance of Facilities $\square$ Lab

System designator(s) (indicate all systems impacted by proposed change):

System Designators and Names

Applicable Drawing Numbers and Revisions

LFP \& LAW Melter Feed Process System 24590-LAW-M5-V17T-00001, Rev. 5

Component designator(s) (indicate all components impacted by proposed change):

Equipment Numbers and Names

Model Designator

LAW melter feed preparation vessels (MFPV), LFP-VSL-00001/3

LFP-VSL-00001/3

Parameters (Indicate all parameters impacted by proposed change. Include current design and proposed values. Indicate applicable references.):

Parameter

Halide, Chromate, and Phosphate limits on LAW Glass

Current Design Value

Proposed Value

None

Calculated per Attachment Al

Proposed Change (Describe in sufficient detail so that it may be accurately translated into a model change.):

Revision 1 of this MCR changed Equation 6 in Attachment A1 only.

Melter studies have shown that halide, chromium, and phosphates can cause precipitation of solids that can interfer the melting process. Pilot melter data now shows what concentrations LAW glass can tolerate. These limits shall be incorporated into the existing LAW glass algorithm per Attachment A1.

References (Include justification basis [required].):

CCN-150795, Halide, Chromate, and Phosphate Impacts on LAW Glass Salt Limits

PNNL 18501, Glass Property Data and Models for Estimating High-Level Waste Glass Volume. 


\title{
Attachment A1
}

\section{Halide, Chromate, and Phosphate Impacts on LAW Glass - Dynamic Flowsheet (G2)}

\author{
(Revision 1 changed Equation 6 only.)
}

Rename $M_{\text {glass }}^{\text {batch }}$ as $\mathrm{M}_{\text {glass.pl }}$ in the model's logic. The final glass calculated will again be called $M_{\text {glass }}^{\text {batch }}$ for calculating the final glass mass and glass formers.

$\mathrm{M}_{\text {glass.p2 }}=\operatorname{MAX}\left(\mathrm{M}_{\text {glass. } \mathrm{p} 1}, \mathrm{M}_{\mathrm{K} 20} / 0.05, \mathrm{M}_{\mathrm{P} 205} / 0.025\right)$

Eq. 1

where: $\mathrm{M}_{\mathrm{K} 2 \mathrm{O}}$ and $\mathrm{M}_{\mathrm{P} 205}$ are the masses of potassium and phosphorous in the waste as the oxide.

Note that CCN 150795 does not give an absolute upper limit for $\mathrm{P}_{2} \mathrm{O}_{5}$ but HLW studies have limited it to $2.5 \mathrm{wt} \%$ per report PNNL 18501, Glass Property Data and Models for Estimating High-Level Waste Glass Volume. HLW glasses are limited to 6.5 combined wt $\%$ for $\mathrm{P}_{2} \mathrm{O}_{5}$ and $\mathrm{CaO}$. Since $\mathrm{LAW}$ glasses uses significant amounts of $\mathrm{CaO}$ as a glass former, this limit will also be observed. Too much $\mathrm{CaO}$ and $\mathrm{P}_{2} \mathrm{O}_{5}$ can lead to a solids precipitate forming on the surface of the molten glass in the melter, which can greatly hinder melter operations.

$\mathrm{g}_{\mathrm{SO} 3}=\mathrm{M}_{\mathrm{SO} 3} / \mathrm{M}_{\text {glass.p2 }}$

Eq. 2

where: $\mathrm{M}_{\mathrm{SO}}$ is the mass of sulfate in the waste as $\mathrm{SO}_{3}$.

$\mathrm{BC}_{\text {Halide }}=\mathrm{IF}\left(\mathrm{g}_{\mathrm{SO} 3}>0.0059,0.0022,-2.1111 \mathrm{~g}_{\mathrm{SO} 3}+0.014656\right)$

Eq. 3

$\mathrm{BC}_{\mathrm{Cr} 2 \mathrm{O} 3}=\mathrm{IF}\left(\mathrm{M}_{\mathrm{P} 2 \mathrm{OS}} / \mathrm{M}_{\text {glass. } \mathrm{p} 2}>0.02499,0.0063, \mathrm{IF}\left(\mathrm{M}_{\mathrm{K} 2 \mathrm{O}} / \mathrm{M}_{\text {glass.p2 }} \leq 0.00540,0.0063,0.008\right)\right) \quad$ Eq. 4

$M_{\text {glass }}^{\text {batch }}=\left(\mathrm{M}_{\text {glass.p2 }},\left(\mathrm{M}_{\mathrm{Cl}}+0.3 \mathrm{M}_{\mathrm{F}}\right) / \mathrm{BC}_{\mathrm{Halide}}, \mathrm{M}_{\mathrm{Cr} 2 \mathrm{O} 3} / \mathrm{BC}_{\mathrm{Cr} 2 \mathrm{O} 3}\right.$

Eq. 5

where: $\mathrm{M}_{\mathrm{Cl}}$ and $\mathrm{M}_{\mathrm{F}}$ are the masses of chlorine and fluorine in the waste.

$\mathrm{M}_{\mathrm{Cr} 2 \mathrm{O} 3}$ is the mass of chromium in the waste as the oxide.

Glass formers are now calculated as before but now using the new $M_{\text {glass }}^{\text {batch }}$ value. However, the glass former amount $\mathrm{A}_{\mathrm{CaO}}$ is not determined yet. Rename $A_{\mathrm{Cro}}^{\text {batch }}$ as $\mathrm{A}_{\mathrm{CaOX}}$ and $A_{\mathrm{SiO} 2}^{\text {batch }}$ as $\mathrm{A}_{\mathrm{SiO} 2 \mathrm{X}}$. The glass is checked to ensure the combined concentration of $\mathrm{CaO}$ and $\mathrm{P} 2 \mathrm{O} 5$ in the glass does not exceed the $6.5 \mathrm{wt} \%$ cited above and the $\mathrm{A}_{\mathrm{CaOx}}$ adjusted accordingly. Therefore:

$A_{C a o}^{\text {batch }}=\mathrm{IF}\left(\left(\mathrm{A}_{\mathrm{CaOX}}+\mathrm{M}_{\mathrm{CaO}}+\mathrm{M}_{\mathrm{P} 2 \mathrm{OS}}\right) / \mathrm{M}_{\text {glass.p2 }}>0.065,0.065-\left(\mathrm{M}_{\mathrm{CaO}}+\mathrm{M}_{\mathrm{P} 2 \mathrm{O} 5}\right) / \mathrm{M}_{\mathrm{glass} . \mathrm{p} 2}, \mathrm{~A}_{\mathrm{CaOX}} / \mathrm{M}_{\mathrm{glass} . \mathrm{p} 2}\right)$ * M $\mathrm{M}_{\text {glass.p2 }}$

Eq. 6

where: $\mathrm{M}_{\mathrm{CaO}}$ is the mass of calcium in the waste as the oxide.

$A_{\text {SiO2 }}^{\text {batch }}=\mathrm{A}_{\mathrm{SiOX}}-\left(\mathrm{A}_{\mathrm{CaO}}-\mathrm{A}_{\mathrm{CaOX}}\right)$ 


\section{Flowsheet Output}

Please print the following values to the law-glass-property print file for validation:

$\mathrm{M}_{\text {glass.p1 }}$

$\mathrm{M}_{\text {glass.p2 }}$

$\mathrm{BC}_{\text {Halide }}$

$\mathrm{BC}_{\mathrm{Cr} 203}$ 


\section{Model Change Request (MCR)}

Page B-1

\section{Attachment B: Change Implementation Plans}

Additional pages may be added to the Change Implementation Plan, as necessary. Additional Change Implementation Plans may be created using the Insert |Change Implementation Plan command. They shall be numbered sequentially and each new one added will supercede all previous Change Implementation Plans in the MCR. All pages must have the MCR number and be numbered sequentially as Page B-x. Enter N/A in any sections that are not applicable.

\section{Change Implementation Plan 1}

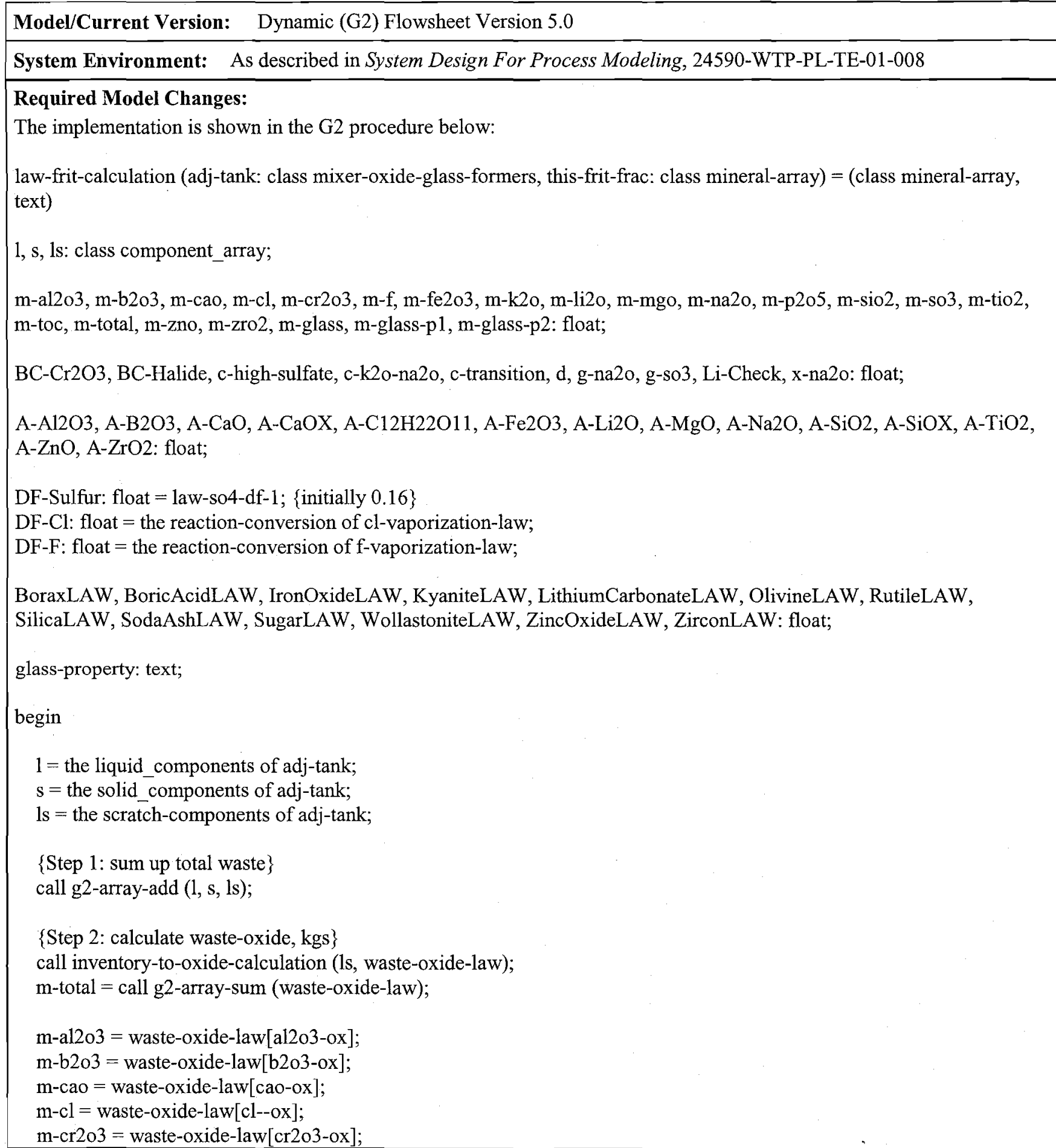




\section{Model Change Request (MCR)}

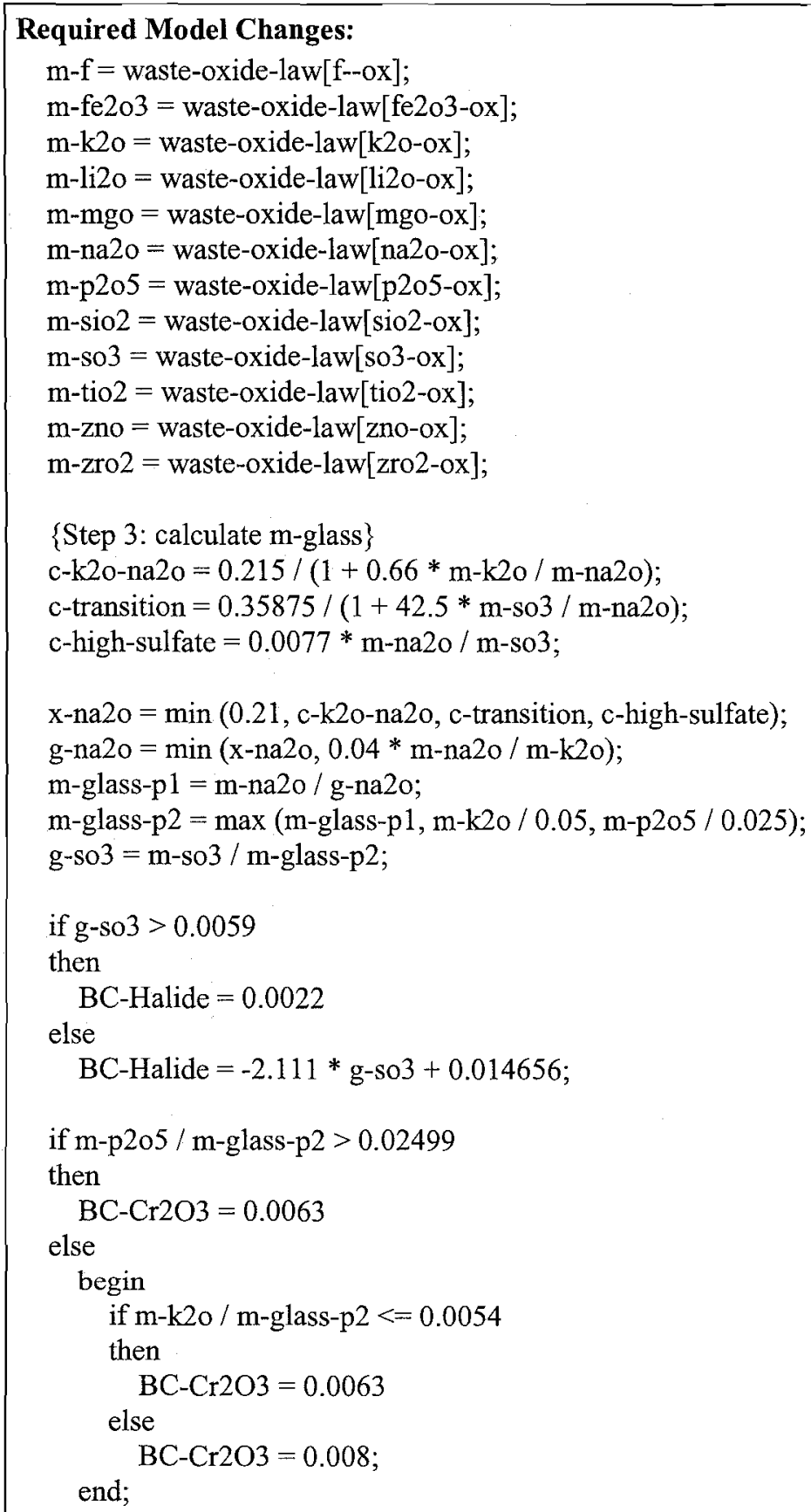

m-glass $=\max (\mathrm{m}$-glass-p2, $(\mathrm{m}-\mathrm{cl}+0.3 * \mathrm{~m}-\mathrm{f}) / \mathrm{BC}-\mathrm{Halide}, \mathrm{m}-\mathrm{cr} 2 \mathrm{o} 3 / \mathrm{BC}-\mathrm{Cr} 2 \mathrm{O} 3)$

\{Step 4: calculate additives\}

$\mathrm{A}-\mathrm{Al} 2 \mathrm{O} 3=\max (0.061, \mathrm{~m}$-al2o3 / m-glass $) * \mathrm{~m}$-glass - m-al2o3;

if $\mathrm{A}-\mathrm{Al} 2 \mathrm{O} 3<0.0$ then $\mathrm{A}-\mathrm{Al} 2 \mathrm{O} 3=0.0$;

$\mathrm{A}-\mathrm{B} 2 \mathrm{O} 3=0.1 * \mathrm{~m}$-glass $-\mathrm{m}-\mathrm{b} 2 \mathrm{o} 3$;

if $\mathrm{A}-\mathrm{B} 2 \mathrm{O} 3<0.0$ then $\mathrm{A}-\mathrm{B} 2 \mathrm{O} 3=0.0$;

$\mathrm{A}-\mathrm{Fe} 2 \mathrm{O} 3=\max (0.055, \mathrm{~m}-\mathrm{fe} 2 \mathrm{o} 3 / \mathrm{m}$-glass $) *$ m-glass $-\mathrm{m}-\mathrm{fe} 2 \mathrm{o} 3$;

if $\mathrm{A}-\mathrm{Fe} 2 \mathrm{O} 3<0.0$ then $\mathrm{A}-\mathrm{Fe} 2 \mathrm{O} 3=0.0$; 


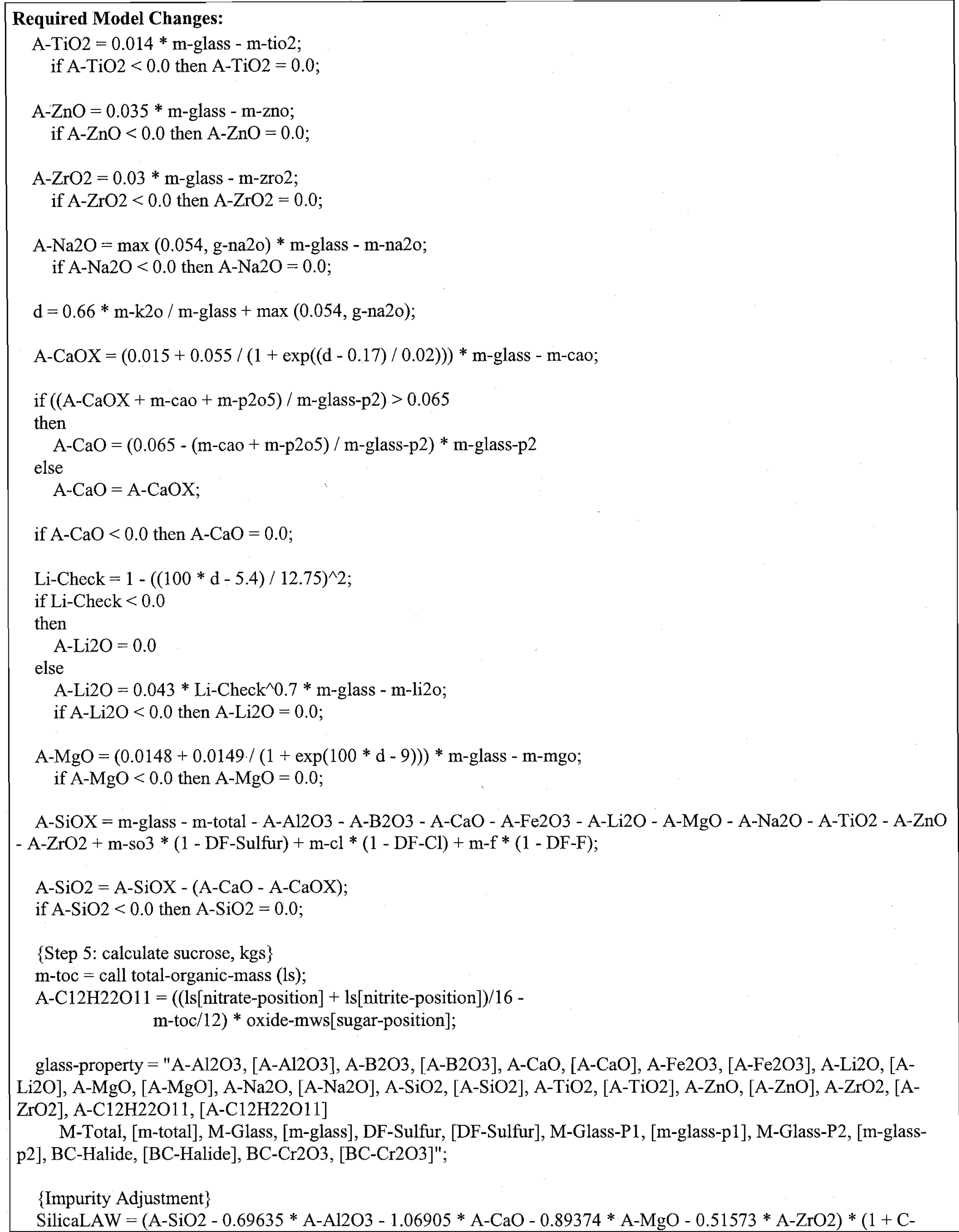




\section{Model Change Request (MCR)}

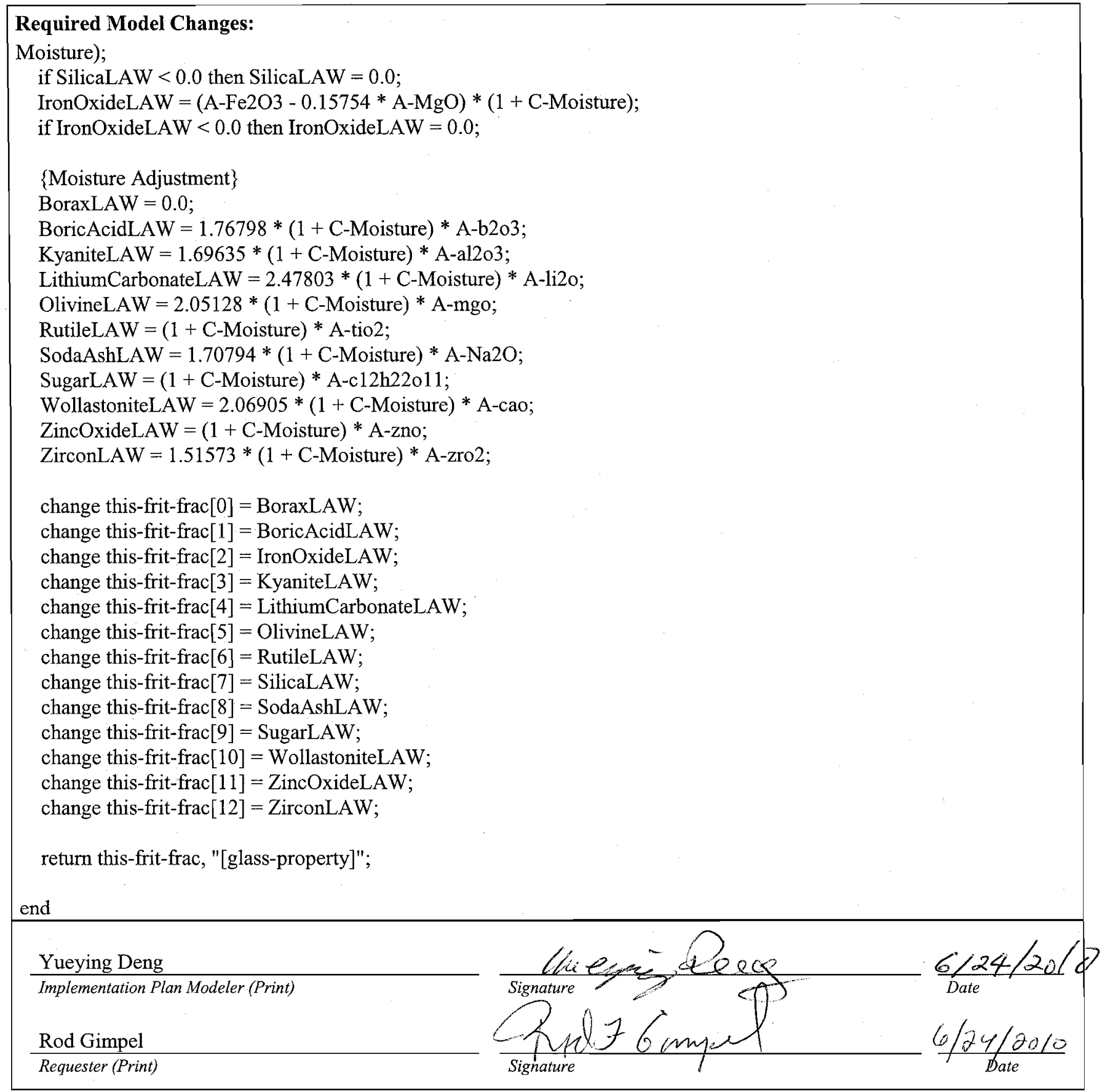

